\title{
A case of asymptomatic incidental live anisakid worm infestation on a large rectal polyp
}

\author{
Shimpei Matsui, ${ }^{1}$ Toshio Uraoka, ${ }^{2}$ Hirotoshi Hasegawa, ${ }^{1}$ Yuko Kitagawa'
}

'Department of Surgery, Keio University, Tokyo, Japan ${ }^{2}$ Tokyo Medical Center, Tokyo, Japan

\section{Correspondence to}

Dr Toshio Uraoka, turaoka@a3.keio.jp

Accepted 25 December 2014

\section{DESCRIPTION}

A 65 -year-old man who had been treated for prostate cancer was noted to have an incidental large rectal tumour on surveillance pelvic MRI. He subsequently underwent a colonoscopy that revealed a penduculated tumour in the rectum. When the tumour was inspected closely (figure 1), a white mobile tubular body was noted on the surface of the tumour. It was strongly suspected to be an anisakis worm. After carefully grasping and removing the worm using biopsy forceps, it was found to be alive and to have meandering movements (figure 2). Subsequently, successful endoscopic submucosal dissection of the tumour was completed (figure 3). Histopathology revealed an anisakiasis and a tubular adenoma with intramucosal cancer. On further interview after the procedure, the patient said he had eaten a raw mackerel for dinner the day before.

Anisakiasis commonly involves the wall of the stomach, causing an inflammatory response and acute symptoms, such as sudden abdominal pain. ${ }^{1}$ Since the incidence of anisakiasis is associated with consumption of raw fish, it is relatively common in Japan due to eating habits. However, it is very rare that the nematode is found alive and causing infestation in the colon. In this rare case, the nematode's body transited through the entire colon alive to finally infest the rectal polyp. To the best of our knowledge, there has been only one case report of anisakiasis of the rectum. ${ }^{2}$ Furthermore, its incidental location on the rectal tumour could possibly be explained by the size of the tumour impeding free flow of stool, resulting in entrapment of the worm on its surface.

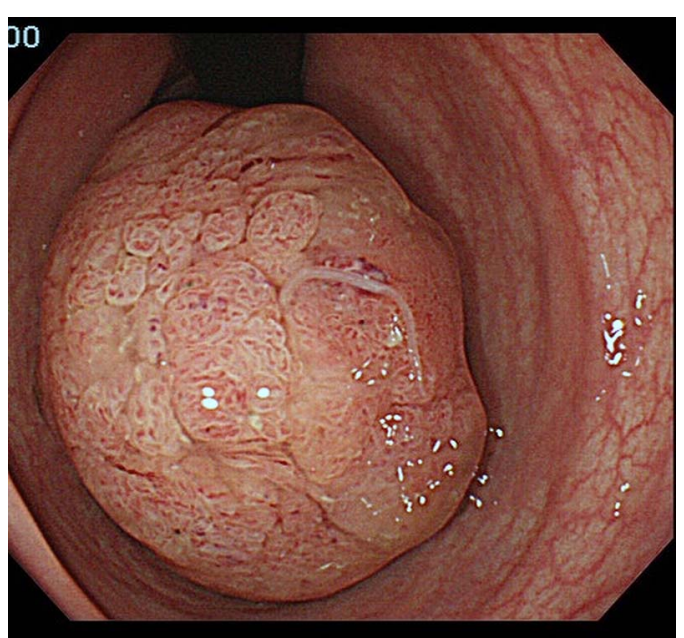

Figure 1 A white mobile tubular part of anisakis worm was noted on the surface of the rectal tumour.

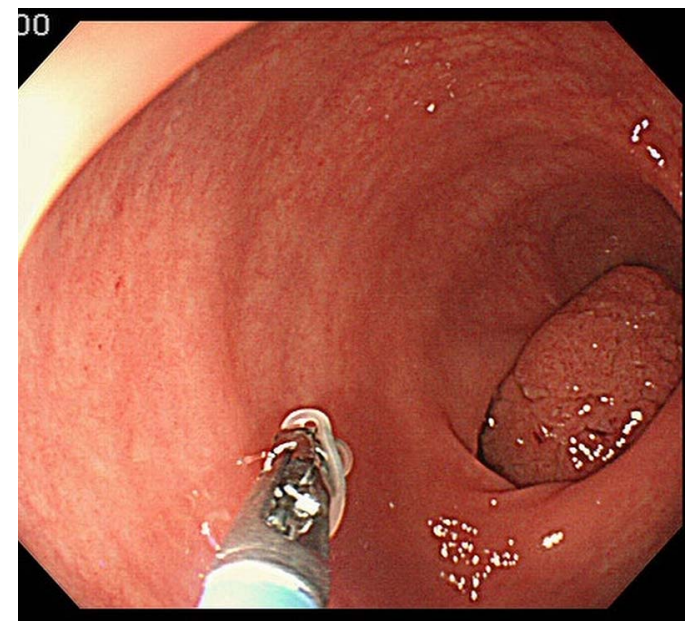

Figure 2 The Anisakis worm was carefully grasped and removed using biopsy forceps.

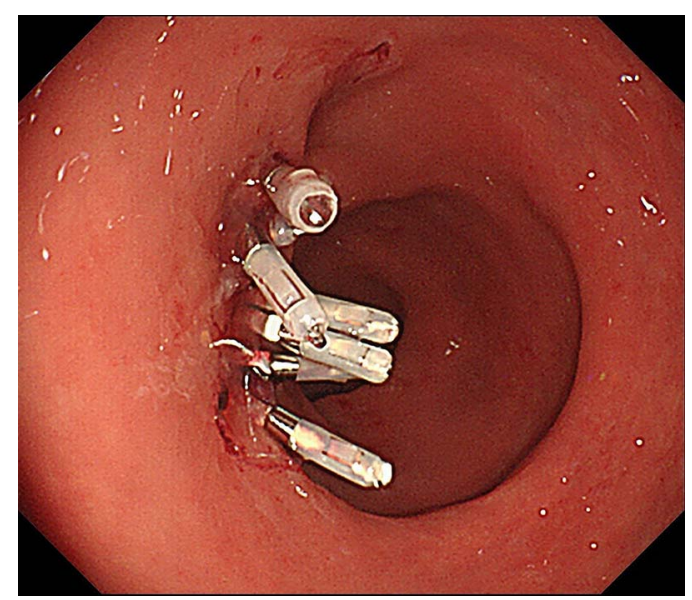

Figure 3 After removal of the anisakis worm, endoscopic submucosal dissection of the tumour was completed.

\section{Learning points}

It is important to inspect and observe any tumour surface beyond assessment of surface and vascular pattern.

- We happened to find the apparent asymptomatic state with rectal anisakid infestation incidentally.

Contributors SM was involved in the study concept, data collection and writing of manuscript. TU was involved in the 
reviewing of manuscript and overseeing the writing of this article. $\mathrm{HH}$ was involved in the reviewing of manuscript. YK was involved in the intellectual contribution and reviewing of manuscript.

Competing interests None.

Patient consent Obtained.

Provenance and peer review Not commissioned; externally peer reviewed.

\section{REFERENCES}

1 Pravettoni V, Primavesi L, Piantanida M. Anisakis simplex: current knowledge. Eur Ann Allergy Clin Immunol 2012;44:150-6.

2 Tokuyama $\mathrm{H}$, Nakayama $\mathrm{Y}$, Tsuno $\mathrm{M}$, et al. A case of anisakiasis of the rectum treated under colonoscopy. Nihon Shokakibyo Gakkai Zasshi 2000;97:616-18.

Copyright 2015 BMJ Publishing Group. All rights reserved. For permission to reuse any of this content visit http://group.bmj.com/group/rights-licensing/permissions.

BMJ Case Report Fellows may re-use this article for personal use and teaching without any further permission.

Become a Fellow of BMJ Case Reports today and you can:

- Submit as many cases as you like

- Enjoy fast sympathetic peer review and rapid publication of accepted articles

- Access all the published articles

- Re-use any of the published material for personal use and teaching without further permission

For information on Institutional Fellowships contact consortiasales@bmjgroup.com

Visit casereports.bmj.com for more articles like this and to become a Fellow 